\author{
D. Kabenov ${ }^{1}$, R. Murathan ${ }^{2}$, V. Golenkov ${ }^{3}$ \\ ${ }^{1}$ Pavlodar State Pedagogical Institute; \\ 2 Ye.A.Buketov Karaganda State University; \\ ${ }^{3}$ Belarusian State University of Informatics and Radio Electronics, Minsk
}

(E-mail:kabenov73@mail.ru)

\title{
Methods of creation of intellectual knowledge evaluation system, students in natural language
}

\begin{abstract}
This article provides a framework for the design and development of intelligent information system of knowledge evaluation using an open form tasks, the «open» (without variants of answers) test tasks are considered as effective. Student's answer entered in a free form gives an opportunity to present student's views on the subject more accurately. And we evaluate his knowledge, and not based on a guessed answer to the question, which proves the effectiveness of the proposed method. This article presents an approach for text analysis in natural language and organization of query in the knowledge based on the ontology.
\end{abstract}

Key words: intelligent system, ontology, text analysis, assessment of knowledge, test systems.

\section{Introduction}

Currently, a large number of organizations (both commercial companies and public educational institutions) develop, acquire and implement a variety of computer-based training. With the develop-ment of computer-based training systems, systems of knowledge monitoring also were developing. Thus, within the framework of distance learning, there are separate subsystems deployed and created which are designed to solve this task. Multimedia technologies developed very strong today, offer a wide range of development tools and a visual representation of tasks intended for students. They also give the student a considerable choice of means of answering questions and fulfilling tasks. Today it is not just a choice of one or more text responses from the options, but the choice of the graphics area in the figure, the correlation, the construction of the expression (for example, an algebraic expression or chemical formula) and even free response [1].

Analysis of the answer given by the student to some question, and comparing his answer with the correct answer stored in the database, gives the degree of truth of the student's answer. The degree of the answer truth, as a rule, has two values: the correct answer or wrong answer, however there are possibly intermediate values between these extreme degrees (e.g., partially correct answer). By degrees of the answers truth to the question, the student' $\mathrm{s}$ level of training is determined and rating is made [2].

Currently, there are many testing systems in various fields of knowledge, for example OLAT (Open Source LMS) [3], Moodle (Moodle Trust, Moodle.org) [4], Sakai (Sakai Foundation, Sakai Project) [5], AuthorWare (Adobe Systems Incorporated) [6]. Most of these tools provide the ability to create multimedia tests, testing for traditional learning and e-learning, saving and transfer of results to the teacher for administration of users and educational groups.

\section{Research conducted in the field of computer-aided control of knowledge}

Acquiring and representing a domain knowledge model is a difficult problem that has been the subject of numerous Artificial Intelligence research projects since research in this field began [7-9]. Knowledge-based systems and expert systems, in particular, must explicitly represent the knowledge and inferences associated with the expertise in this domain.

For many countries, the e-learning theory emphasizes the importance of the specified cognitive process and personalized learning [10]. Knowledge monitoring and evaluation is an intellectual challenge, requiring the highquality solutions, which will help to get to a new level in the teaching procedure, as it could allow implementing the concept of the individual approach to learning on a massive scale. Nowadays the automated knowledge test has become very popular, firstly, as it saves the teacher's working hours, relieves him from the routine work and 
ensures an objective evaluation of knowledge, the results of which do not depend on the subjective opinions of different teachers.

The paper [11] presents newly developed computerized system of constructive multiple-choice testing. The system combines short answer (SA) and multiple-choice (MC) formats by asking examinees to respond to the same question twice, first in the SA format, and then in the MC format.

The papers $[12,13]$ describe methods of implementation of a control mechanism of student knowledge with the help of fuzzy set theory combined with neural network technology. The papers apply some serious improvements in the logic of evaluation of knowledge, and methodologies of data interpretation of student responses. The presented architecture has typical configuration of hardware and software in an intranet environment of educational institutions.

The article [14] considered content of compute-aided assembled examination in natural science disciplines, stated requirements to «assembled examination» in general, and addressed some types of tasks on such examinations.

Analysis of the aforementioned work shows that ordinary linear tests with simple forms of the answer do not quite meet the requirements of comprehensive control of students' knowledge. First of all it refers to natural and mathematical sciences, which peculiarity lies in the close relationship of concepts, themes and sections of the course; as the main criterion for learning is the ability to solve tasks of different nature and level of complexity. Therefore development of the adaptive, nonlinear, and intellectual testing methods with more various types of tasks and answers' forms is needed. At the same time, new testing systems should incorporate all the achievements of previous generations of the knowledge control tools.

\section{Ontology and Ontology Engineering}

Before going into further detail, it is important to define the notion of ontology. Very briefly, ontology is a formal specification of a conceptualization (in this case, a domain) and it includes the definition of classes, objects, properties, relationships and axioms. Ontologies are expressed using a formal language such as RDF or OWL and support automatic inference. Generally, ontologies involve a kind of consensus within a community, meaning that they formalize concepts that are generally accepted within this community. There are many kinds of ontologies such as upper-level ontologies, task ontologies and domain ontologies. We are interested here in domain ontologies.

As previously pointed out, the concept of a domain ontology as envisioned by the eLearning community is relatively new in the field of ITS. However, domain ontology engineering is a growing research area that has received much attention in other fields and it is the corner stone of the Semantic Web. Ontology engineering is a field that explores the methods and tools for handling the ontology lifecycle.

It requires a general and domain-independent methodology that provides guidance for ontology building, refinement and evaluation [15]. The ontology life-cycle can be schematized in four main stages: the specification stage, the formalization stage, the maintenance stage, and the evaluation stage.

- the specification stage identifies the purpose and scope of the ontology. Generally, this relies a lot on domain experts and needs to define the competency questions that the ontology has to to answer. It is also dependent on the application that is going to be used by the ontology;

- the formalization stage produces a conceptual and formal model that meets the requirements of the specification stage;

- the maintenance stage keeps track of the ontology's updates and evolution, and checks its consistency;

- finally, the evaluation stage analyzes the resulting ontology and checks if it meets the initial needs and has the desired features.

At this point, we are interested in the formalization stage and how it can benefit from automated methods for knowledge acquisition. In fact, the most common and successful techniques for domain engineering are generally manual, and the best ITS authoring tools can help the expert formalize his knowledge but these tools are generally far from being part of an automated procedure. It is therefore worthwhile to explicitly state the steps that can be automated to alleviate the task of human experts and the burden of knowledge acquisition. Ontology learning techniques have been adopted to achieve this goal [16]. These learning techniques can vary according to the degree of automation (semi-automatic, fully automatic), the ontological knowledge that has to be extracted (concepts, taxonomy, conceptual relationships, attributes, instances, axioms), the knowledge sources (texts, databases, xml documents, etc.) and finally the purpose (creating ontologies from scratch and/or updating existing ontologies). 
In order to build ontology of Geometry, it is beneficial to understand the need of ontology and some works concerned of the ontology-based text mining. Ontology is an explicit formal specification of the terms in explicit specification the domain and relations among them [17]. Ontologies are useful as means to support sharing and reutilization of knowledge [18]. This reusability approach is based on the assumption that if a modeling scheme, i.e., ontology, is explicitly specified and mutually agreed upon by the parties involved, and then it is possible to share, reutilize and extend knowledge. Many disciplines now develop standardized ontologies that domain experts can use to share and annotate information in their fields. Problem-solving methods, domain-independent applications, and software agents use ontologies and knowledge bases built on ontologies as data [19].

Reusing existing ontologies may be a requirement if our system needs to interact with other applications that have already committed to particular ontologies or controlled vocabularies [20]. There are libraries of reusable ontologies on the Web and in the literature, for example, the Ontolingua ontology library [21] or the DAML ontology library [22]. The need of ontologies is connected with the inability of the existing methods to adequately automatically process native-language texts. For high-quality word processing, you must have a detailed description of the problem area with a lot of logical links that show the relationships between the terms field. The use of ontologies can provide a native language text in such a way that when it becomes available-for-automatic processing [23].

Within the OSTIS project (The Open Semantic Technologies for Designing the Intelligent Systems) the «Variational Geometric Solver» help system has been generated. On the basis of the Geometry domain ontology. The system operation is organized so, as to answer the questions asked by a user and to give him answers to the questions, as well as to complete the geometric tasks. In the work «The Semantic Technology for the Component Design of the Intelligent Task Solvers» the authors [24] have presented the features of the help system of the intelligent geometric solver.

\section{Geometry ontology}

An ontology is a formal explicit description of concepts in a domain of discourse (classes (sometimes called concepts)), properties of each concept describing various features and attributes of the concept (slots (sometimes called roles or properties)), and restrictions on slots (facets (sometimes called role restrictions)) [19]. Ontology together with a set of individual instances of classes constitutes a knowledge base.

Development of ontology includes [19]:

- defining classes in the ontology;

- arranging the classes in a taxonomic (subclass - superclass) hierarchy;

- defining slots and describing allowed values for these slots;

- filling in the values for slots for instances.

Our ontology consists of the several levels. The first level contains the classes, instances of which cannot be received from the other classes. The Right Class Shape represents all the entities of the outline shapes. The Specific Right Shapes are the instances of this class.

The front levels are generated by the reasoning process, i.e. using the ontology reasoning block or by various modules, opened by the Reasoning Manager. The higher the level is, the more detailed the information is; for example, on the third level a figure is classified as a two-dimensional one, and in turn, it is classified as a polygon, the polygon - as a convex polygon, the convex polygon - as a quadrilateral, the quadrilateral - as a parallelogram, the parallelogram - as a rectangle or a diamond, the rectangle or the diamond - as a square respectively (Fig. 1).

We arrange classes in a hierarchical taxonomy with a question if, when being an instance of one class, the entity is always (that is, by definition) an instance of another class. If the A class is a superclass of the B class, then every instance of the B class is also the instance of the A superclass. 


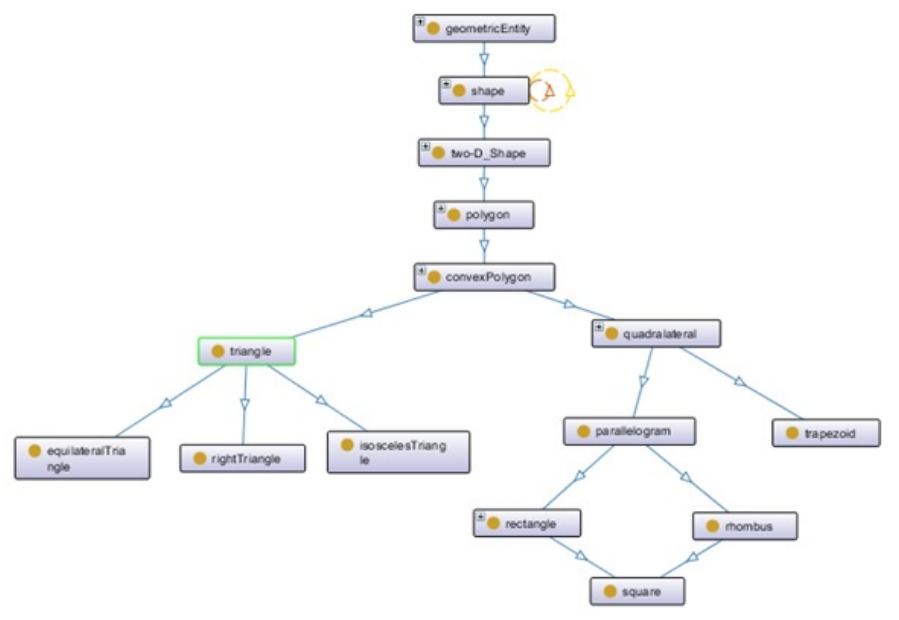

Figure 1. Ontology fragment geometry

\section{Data analysis on the natural language based on the ontology}

As compared with the traditional forms of learning, the distance learning has several advantages: adjustment to the students' individual peculiarities, a free choice of time, a place and an education level, the use of the new training methods, the modern means of communication and the information transmition between the students and teachers. Nevertheless, knowledge monitoring is particularly important due to the absence of the direct contact of students and professors.

Managing the knowledge monitoring is closely related to the issue of selecting the questions type, the method of generating the test path and the answer validation method.

For the purpose of solving these problems, we offer the concept of the intelligent test system based on the Geometry domain ontology.

The following types of questions for the knowledge quality supervision are suggested:

- the closed-ended test questions, i.e. when the multiple choice questions are suggested, and one of the answers to the question is right and should be chosen;

- the open-ended test questions, i.e. the questions without the proposed alternate answers (these questions are useful for evaluating the knowledge of terms, definitions, concepts, etc.);

- the situation tests, i.e. a set of the test tasks designed for solving the problematic situations (the geometric tasks).

One of the artificial intelligence methods for representing knowledge in a natural language is the semantic network. A semantic network is the domain information model, that has the form of the directed graph, which nodes correspond to the domain entities, and the arcs (edges) set the relationship between them. Concepts, events, properties, processes could be the entities. Thus, the semantic networks are one of the ways to represent knowledge in a natural language. Over the last years in the works of many scientists the special graphdynamic models - the semantic models of representing and processing the knowledge based on the semantic networks [25], have been suggested to use as a formal framework for the designed intelligent systems, the abstract logical semantic models of the intelligent systems.

In his work [26] Golenkov suggested to generate the formal tools for describing the semantics of different knowledge types, as well as the formal tools for describing knowledge processing on the semantic level. A system of the intelligent evaluation of the students' knowledge in the case of the Geometry domain could be developed upon the proposed principles.

The text analysis in a natural language is suggested for analyzing and examining the students' answers to the open-ended test questions. The knowledge description in the Geometry domain was presented as ontology $[27]$.

Let's give a brief description of the proposed method of checking the geometric task solution based on the ontologies. The texts of the geometric task are a set of the coherent sentences. They include simple and complex sentences, incomplete sentences (with anaphora and ellipses). Formal understanding of the geometric tasks' text is their representation in the knowledge language in the domain of Geometry ontology. This representation 
should be connected and extended by filling the slot value for the cases, which describe the situation presented by the text.

Reviewing the whole process of analyzing the geometric tasks seems to be impossible in this article. Therefore, let us consider the structure of the situation, which should be resulted from the ontology based on the linguistic analysis for a geometric task.

The Task. A rectangular quadrilateral, which sides are $8 \mathrm{~cm}$ and $18 \mathrm{~cm}$, is given. The areas of the rectangular quadrilateral and the square are equal. Find the square side.

\section{Linguistic analysis of the task's text}

Our task consists of three sentences. These sentences pass morphological analysis in turn. That is the roots of words is determined and they will be stored in the base of morphemes.

From the first sentence it finds a word rectangular quadrangle - noun, and on ontology is rectangle. Side noun, on ontology is edge, length is also a noun, on ontology is length, 8 - numeral, 18 - numeral. But there is no length of sides of a rectangular quadrangle in the global ontology, but we added them to the local ontology. Here, the global ontology refers to the ontology of geometry, and the local ontology is constructed from conditions of the task.

From the second sentence it finds a word square - noun, and on ontology is area, rectangular quadrangle noun, and on ontology is rectangle, quadrate - noun, and on ontology square, equal - adjective indicates that the area of a rectangular quadrangle and quadrate are equal.

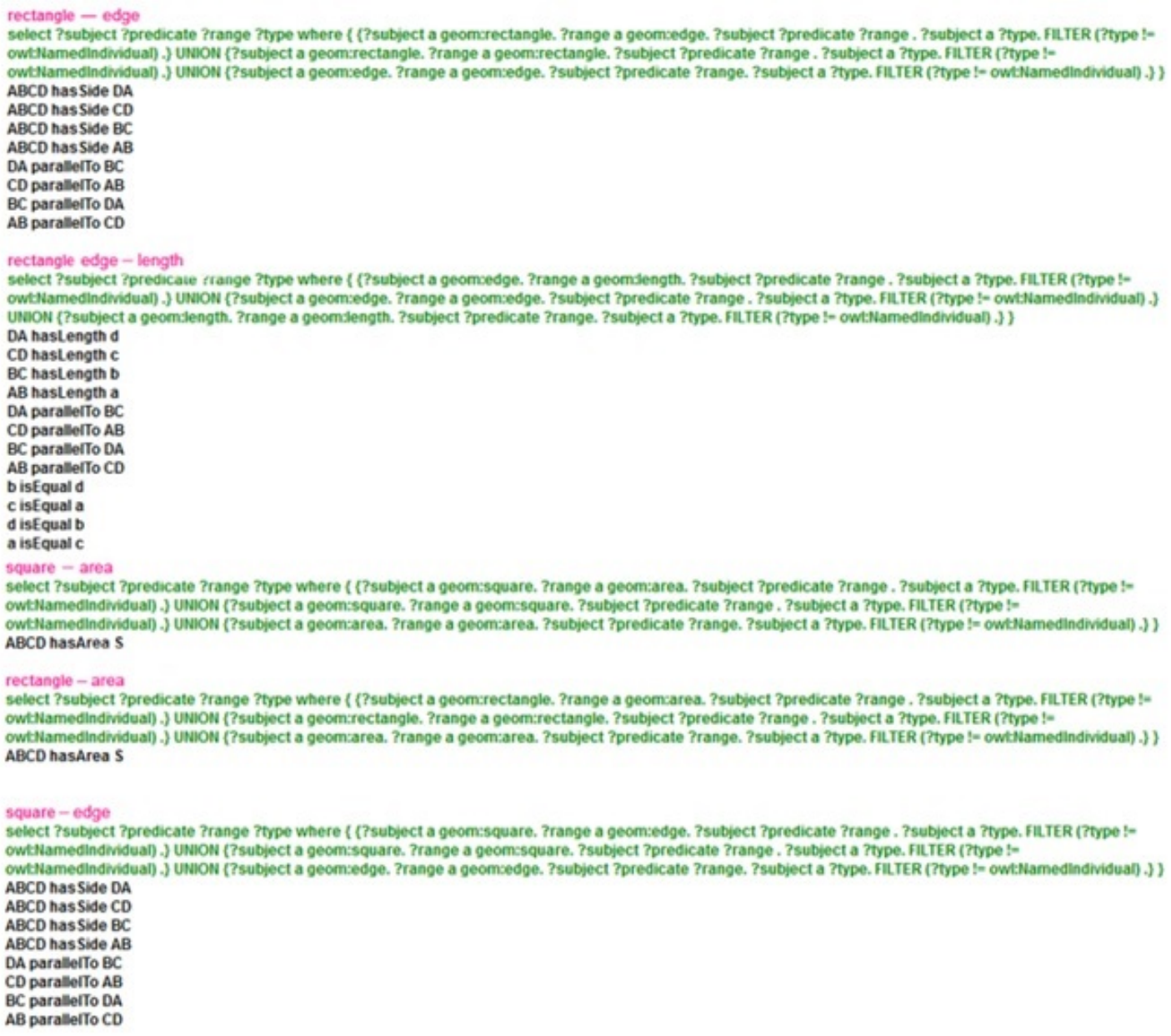

Figure 2. SPARQL query to the knowledge base 
Now, the third sentence is analyzed. Hence, the word find - verb, length - noun, on ontology is length, side - noun, on ontology is edge, quadrate - noun, and on ontology is square.

After all the words have been morphologically analyzed, the following questions are asked: To find what? Side. Of what? - Of Quadrate.

After linguistic analysis of the task's text, a query is made to ontology in the language of query SPARQL [28]. Having made a query, we find that there is an individual of rectangular quadrangle ABCD. ABCD has sides, sides are parallel to each other, sides have lengths and sides are equal to each other. Rectangular quadrangle has an area. Quadrate has an area. SPARQL queries to the knowledge base shown in figure 2.

The table listing all relationships between the properties of the individual rectangular quadrangle is formed according to the results of query to the ontology. Local ontology describes the properties of the class elements that will be needed for this task solution. To solve the task you need to determine the sides of the rectangular quadrangle, lengths of the sides, and the numerical designation of lengths. Determine that the sides are equal and parallel. Quadrangle has an area and is equal to the quadrate area.

We use description logic [29]. With description logic we determine classes and draw the geometry upon the global ontology and fill them with data from the task. Figure 3 shows a table of the relationship between the classes and properties of individuals.

$\begin{array}{lll}\text { rectangle_rectangle_ABCD hasSide } & \text { rectangle_edge_DA } \\ \text { rectangle_rectangle_ABCD hasSide } & \text { rectangle_edge_CD } \\ \text { rectangle_rectangle_ABCD hasSide } & \text { rectangle_edge_BC } \\ \text { rectangle_rectangle_ABCD hasSide } & \text { rectangle_edge_AB } \\ \text { rectangle_edge_DA } & \text { paralleITo } & \text { rectangle_edge_BC } \\ \text { rectangle_edge_CD } & \text { paralleITo } & \text { rectangle_edge_AB } \\ \text { rectangle_edge_BC } & \text { paralleITo } & \text { rectangle_edge_DA } \\ \text { rectangle_edge_AB } & \text { paralleITo } & \text { rectangle_edge_CD } \\ \text { rectangle_edge_DA } & \text { hasLength rectangle_length_d } \\ \text { rectangle_edge_CD } & \text { hasLength rectangle_length_c } \\ \text { rectangle_edge_BC } & \text { hasLength rectangle_length_b } \\ \text { rectangle_edge_AB } & \text { hasLength rectangle_length_a } \\ \text { rectangle_edge_DA } & \text { paralleITo } & \text { rectangle_length_BC } \\ \text { rectangle_edge_CD } & \text { paralleITo } & \text { rectangle_length_AB } \\ \text { rectangle_edge_BC } & \text { paralleITo } & \text { rectangle_length_DA } \\ \text { rectangle_edge_AB } & \text { paralleITo } & \text { rectangle_length_CD } \\ \text { rectangle_length_b } & \text { isEqual } & \text { rectangle_length_d } \\ \text { rectangle_length_c } & \text { isEqual } & \text { rectangle_length_a } \\ \text { rectangle_length_d } & \text { isEqual } & \text { rectangle_length_b } \\ \text { rectangle_length_a } & \text { isEqual } & \text { rectangle_length_c } \\ \text { rectangle_length_b } & \text { isEqual } & \text { rectangle_Number_8 } \\ \text { rectangle_length_d } & \text { isEqual } & \text { rectangle_Number_8 } \\ \text { rectangle_length_c } & \text { isEqual } & \text { rectangle_Number_18 } \\ \text { rectangle_length_a } & \text { isEqual } & \text { rectangle_Number_18 } \\ \text { square_square_ABCD } & \text { hasArea } & \text { square_area_S } \\ \text { rectangle_rectangle_ABCD hasArea } & \text { rectangle_area_S }\end{array}$

Figure 3. Derivation of relationships and properties using description logic 
As the table shows, all the data and relationships between them necessary for solving the task are established. The next step according to the formula calculates the area of rectangular quadrangle, and so on. For this purpose the markup language of mathematical formulas MathML is used. Input and storage of formulas required for the task solution will be made in the markup language of mathematical formulas MathML. Intelligent system of knowledge evaluation has support for editing, viewing, and solution of mathematical expressions in the markup language of mathematical formulas MathML.

\section{Conclusions and succeeding activity}

This article presents an approach based on ontology, which solves the problem of the text analysis in natural language. We have proposed a method to use Geometry domain ontology to automatically check responses to «open» questions (without variants).

Our concept of creating a computer-aided testing system uses results of intelligent evaluation of the user level and provides a set of tests that are adapted to the student's training level. Knowledge control system distributes the questions in complexity, based on data obtained during testing. This enables the construction of adaptive tests that do not require correction at the user level.

Mathematical models and algorithms created using artificial intelligence methods and languages for knowledge representation will create real smart human-machine system, because they will interact in natural language, which certainly affect the development of smart technologies in our country.

Further research in the framework of the methodological aspects of the automated control of knowledge will concern evaluation of students' knowledge and the development of databases of test questions of different types and different levels of complexity.

\section{References}

1 Маслов С.И. Информатизация образования: направления, средства, технологии: пособие для системы повышения квалификации. - М.: Изд-во МЭИ, 2004. - С. 868.

2 Панченко В.М., Шорохов М.И. Компьютерные технологии обучения. Мониторинг качества обучения в техническом вузе на основе ретроспективного комплекса: учеб. пособие. - М.: МИРЭА, 2006. C. 156 .

3 OLAT - The Open Source LMS. [Online] Available from: - [ER]. Access mode: www.olat.org/ website/en/ html/index.html.

4 Moodle Trust, Moodle.org, Open-source Community-based Tools for Learning. [Online] Available from: - [ER]. Access mode: www.moodle.org.

5 Sakai Foundation, Sakai Project. [Online] Available from: - [ER]. Access mode: http: sakaiproject.org/

6 Adobe Systems Incorporated, Adobe Authorware. [Online] Available from: - [ER]. Access mode: www.adobe.com/products/authorware/

7 Clancey B. Acquiring, representing and evaluating a competence model of diagnostioc strategy. Technical Report: CS-TR-85-1067, Stanford University. - 1985.

8 Brachman R.J., Levesque H.J. Knowledge Representation and Reasoning. Morgan Kaufmann, San Francisco, 2004.

9 Russell S.J., Norvig P. Artificial Intelligence: A Modern Approach, 3rd edn. Prentice Hall, Upper Saddle River. - 2009. - No. 43 (1). - P. 5-16.

10 Jui-long H. Trends of E-learning Research from 2000 to 2008: Use of text mining and bibliometrics. British Journal of Educational Technology. - 2012.

11 Park J. Constructive multiple-choice testing system. British J. of Educational Technology. Special Issue: Learning objects in progress. - 2010. - No. 41 (6). - P. 1054-1064.

12 Shahbazova Sh., Freisleben B.A. Network-Based Intellectual Information System for Learning and Testing. Proceedings of the Fourth International Conference on Application of Fuzzy Systems and Soft Computing, Siegen, Germany. - 2000. - P. 308-313.

13 Shahbazova Sh. Application of Fuzzy Sets for Control of Students Knowledge. Application Comput. Math. - 2011. - No. 10 (1). - P. 195-208. 
14 Кусманов К.Р., Копеев Ж.Б., Панков П.С. Содержание и разработка компьютерных комплексных экзаменов по математике и информатике. LXXV Междунар. науч. практ. конф. «Проблемы соотношения межличностных взаимодействий и образовательных технологий в общественных отношениях». - Лондон, 2014. - С. 11-13.

15 Aussenac-Gilles N. et all. Revisiting Ontology Design: A Methodology Based on Corpus Analysis. In: Dieng, R., Corby, O. (eds.) EKAW 2000. LNCS (LNAI), Springer, Heidelberg. — 2000. — Vol. 1937. — P. $172-188$.

16 Guarino N., Welty C. Evaluating Ontological Decisions with OntoClean. Communications of the ACM. - 2002. - No. 45(2). - P. 61-65.

17 Gruber T.R. Toward principles for the design of ontologies used for knowledge sharing. International Journal of Human-Computer Studies. - 1995. - No. 43(5, 6). - P. 907-928.

18 Decker S. et al. Ontobroker: Ontology based access to distributed and semi-structured information. DS-8: Semantic Issues in Multimedia Systems. - 1999.

19 Noy N.F. and McGuinness D.L. Ontology Development 101: A Guide to Creating Your First Ontology'. Stanford Knowledge Systems Laboratory Technical Report KSL-01-05 and Stanford Medical Informatics Technical Report SMI-2001-0880. - 2001.

20 Maedche A. et all. Bootstrapping an Ontology-based Information Extraction System. Intelligent exploration of the web, Physica-Verlag GmbH Heidelberg, Germany. — 2003. - P. 345-359.

21 The Ontolingua ontology library. [Online] Available from:- [ER]. Access mode: www.ksl.stanford.edu/software/ontolingua/

22 The DAML ontology library. [Online] Available from:- [ER]. Access mode: www.daml.org/ontologies

23 Заливако С.С., Шункевич Д.В. Семантическая технология компонентного проектирования интеллектуальных решателей задач: материалы междунар. науч.-техн. конф. «Открытые семантические технологии проектирования интеллектуальных систем». - Минск, 2012. - С. 297-314.

24 Khakhalin G. et all. Integration of the Image and Nutlet Analysis. Synthesis Systems. Intelligent Data Analysis for Real-Life Applications: Theory and Practice. - IGIGlobal, 2012.

25 Sowa J. Conceptual Graphs. Handbook of Knowledge Representation, Elsevier. - 2008. - P. $213-237$.

26 Голенков В.В., Гулякина Н.А. Графодинамические модели параллельной обработки знаний: принципы построения, реализации и проектирования: материалы междунар. науч.-техн. конф. «Открытые семантические технологии проектирования интеллектуальных систем». - Минск, 2012. - С. $23-52$.

27 Kabenov $D$ et all. Intelligent system of knowledge control for e-learning // Journal of International Scientific Publ.: Educational Alternatives. - 2012. - No. 10(2). - P. 250-260.

28 BSBM V3 Results. Prof.'s Dr. Christian Bizer Home page, Institute fur Wirtschaftsinformatik. - [ER]. Access mode: www.wiwiss.fu-berlin.de/bizer/Berlin/SPARQLBenchmark/results/V6/ index.html.

29 Лапшин B.A. Онтологии в компьютерных системах. - М.: Научный мир, 2010. - C. 224.

\author{
Д. Кабенов, Р. Муратхан, В. Голенков
}

\title{
Білім алушылардың білімін табиғи тілде бағалаудың зерделі жүйесін жасау әдістері
}

\begin{abstract}
Мақалада білімді бақылаудың зерделі ақпараттық жүйесін жобалау мен жасаудың негізі ұсынылды. Бұл білімді меңгеру үшін «ашық» (жауап үлгілері жоқ) тест тапсырмаларының нәтижелілігі аса зор. Біз қойған сұраққа жауапты таңдап алуын емес, ал оқушының білімін бағалайтын боламыз, өз кезінде ол ұсынылып отырған әдістің тиімділігін дәлелдейді. Авторлар білім алушының табиғb тілдегі жауаптарын автоматты түрде бағалу үшін онтологияға негізделген мәтінді талдау әдісін ұсынды.
\end{abstract}


Д. Кабенов, Р. Муратхан, В. Голенков

\title{
Методы создания интеллектуальной системы оценки знаний обучающихся на естественном языке
}

\begin{abstract}
В статье предложена основа для проектирования и разработки интеллектуальной системы контроля и оценки знаний с использованием ответа на естественном языке. Для управления этим знанием «открытые» (без вариантов ответа) тестовые задания являются более эффективными. Оцениваем знания, а не отгадывание ответа на заданный вопрос, что доказывает эффективность предлагаемого метода. В связи с этим авторами предложен новый подход анализа текста, основанного на онтологии, для автоматической оценки ответов обучаемых на естественном языке.
\end{abstract}

\section{References}

1 Maslov S.I. Moscow Economic Institute, 2004, p. 868.

2 Panchenko V.M., Shorochov M.I. Moscow Institute of Radio Engineering, Electronics and Automation, 2006, p. 156.

3 OLAT - The Open Source LMS. [Online] Available from, [ER]. Access mode: www.olat.org/ website/en/ html/index.html

4 Moodle Trust, Moodle.org, Open-source Community-based Tools for Learning. [Online] Available from, [ER]. Access mode: www.moodle.org

5 Sakai Foundation, Sakai Project. [Online] Available from, [ER]. Access mode: http: sakaipro-ject.org/

6 Adobe Systems Incorporated, Adobe Authorware. [Online] Available from, [ER]. Access mode: www.adobe. com/products/authorware/

7 Clancey B. Acquiring, representing and evaluating a competence model of diagnostioc strategy, Technical Report: CS-TR-85-1067, Stanford University, 1985.

8 Brachman R.J., Levesque H.J. Knowledge Representation and Reasoning, Morgan Kaufmann, San Francisco, 2004.

9 Russell S.J., Norvig P. Artificial Intelligence: A Modern Approach, 3rd edn. Prentice Hall, Upper Saddle River, 2009, 43 (1), p. 5-16.

10 Jui-long H. Trends of E-learning Research from 2000 to 2008: Use of text mining and bibliometrics. British J. of Educational Technology, 2012.

11 Park J. Constructive multiple-choice testing system. British J. of Educational Technology. Special Issue: Learning objects in progress, 2010, 41 (6), p. 1054-1064.

12 Shahbazova Sh.B., Freisleben A. Network-Based Intellectual Information System for Learning and Testing. Proceedings of the Fourth International Conference on Application of Fuzzy Systems and Soft Computing, Siegen, Germany, 2000, p. 308-313.

13 Shahbazova Sh. Application of Fuzzy Sets for Control of Students Knowledge, Application Comput. Math., 2011, 10(1), p. 195-208.

14 Kusmanov K.R., Kopeev Zh.B., Pankov P.S. The content of computer-aided complex examinations in natural science disciplines: materials LXXV International Research and Practice Conference, International Academy of Science and Higher Education: London, 2014, p. 11-13.

15 Aussenac-Gilles N. et all. Revisiting Ontology Design: A Methodology Based on Corpus Analysis, In: Dieng, R., Corby, O. (eds.) EKAW 2000. LNCS (LNAI), Springer, Heidelberg, 2000, 1937, p. 172-188.

16 Guarino N., Welty C. Evaluating Ontological Decisions with OntoClean, Communications of the ACM, 2002, 45(2), p. 61-65.

17 Gruber T.R. Journal International of Human-Computer Studies, 1995, 43(5-6), p. 907-928.

18 Decker S. et al. Ontobroker: Ontology based access to distributed and semi-structured information, DS-8: Semantic Issues in Multimedia Systems, 1999. 
19 Noy N.F., McGuinness D.L. Ontology Development 101: A Guide to Creating Your First Ontology', Stanford Knowledge Systems Laboratory Technical Report KSL-01-05 and Stanford Medical Informatics Technical Report SMI-2001-0880, 2001.

20 Maedche A. et all. Bootstrapping an Ontology-based Information Extraction System, Intelligent exploration of the web, Physica-Verlag GmbH Heidelberg, Germany, 2003, p. 345-359.

21 The Ontolingua ontology library, [Online] Available from, [ER]. Access mode: www.ksl.stanford.edu/software/ontolingua/

22 The DAML ontology library, [Online] Available from, [ER]. Access mode: www.daml.org/ontologies

23 Shunkevich D.V., Zalivako S.S. Proceedings of International Conference Open semantic technology of intelligent systems, Minsk, 2012, p. 297-314.

24 Khakhalin G. et all. Integration of the Image and Nutlet Analysis, Synthesis Systems, Intelligent Data Analysis for Real-Life Applications: theory and Practice, IGIGlobal, 2012.

25 Sowa J. Conceptual Graphs. Handbook of Knowledge Representation, Elsevier, 2008, p. 213-237.

26 Golenkov V.V., Guliakina N.A. Proceedings of International Conference Open semantic technology of intelligent systems, Minsk, 2012, p. 23-52.

27 Kabenov D. et all. Journal of International Scientific Publ.: Educational Alternatives, 2012, 10(2), p. 250260.

28 BSBM V3 Results. Prof.'s Dr. Christian Bizer Home page, Institute fur Wirtschaftsinformatik, [ER]. Access mode: www.wiwiss.fu-berlin.de/bizer/Berlin/SPARQLBenchmark/results/V6/ index.html.

29 Lapshin V.A. Ontology in computer systems, Moscow: Nauchnyi mir, 2010, p. 224. 